\title{
ANALISIS KOEFISIEN ALIRAN PERMUKAAN DENGAN MENGGUNAKAN METODE BRANSBY-WILLIAMS DI SUB DAERAH ALIRAN SUNGAI BABURA PROVINSI SUMATERA UTARA
}

\section{Anik Juli Dwi Astuti ${ }^{1}$, Eni Yuniastuti1, Dwi Wahyuni Nurwihastuti ${ }^{1}$, Retno Triastuti ${ }^{2}$} 1Jurusan Pendidikan Geografi, Fakultas Ilmu Sosial, Universitas Negeri Medan 2 BPDASHL Wampu Sei Ular, Kementerian Lingkungan Hidup dan Kehutanan Email: anikjuli@unimed.ac.id

\begin{abstract}
Abstrak
Daerah penelitian adalah sub Daerah Aliran Sungai Babura yang mempunyai luas 4921,88 Ha. Tujuan dari penelitian ini adalah 1) menganalisis besarnya koefisien aliran permukaan menggunakan metode Bransby-William di Sub Daerah Aliran Sungai Babura, 2) menganalisis distribusi nilai koefisien aliran di Sub Daerah Sungai Babura. Teknik pengumpulan data pada penelitian ini menggunakan metode survey baik survey instansional maupun lapangan. Survei instansional digunakan untuk memperoleh data curah hujan dan penutup lahan sedangkan survey lapangan digunakan untuk mendapatkan data tekstur tanah dan kemiringan lereng. Selanjutnya hasil dianalisis dengan menggunakan analsis deskriptif dan spasial. Hasil penelitian menunjukkan bahwa koefisien aliran di Sub Daerah Aliran Sungai Babura berkisar 0,4 - 0,55 dengan rata-rata 0,475. Dengan mendasarkan pada nilai koefisien aliran tersebut dapat dikatakan bahwa sub DAS Babura masih dalam kondisi baik. Besarnya koefisien aliran di SubDAS Babura bervariasi dimana pada daerah hulu nilai koefisien aliran permukaan berkisar antara 0,4 0,45 sedangkan di daerah hilir sungai pada kisaran nilai 0,5 - 0,55.
\end{abstract}

Kata kunci : koefisien aliran, Bransby-William, sub Daerah Aliran Sungai, Babura

\section{Abstract}

The research located in Babura watershed which has wide of $4921.88 \mathrm{Ha}$. The purposes of this research are 1) to analyze runoff coefficient using Bransby-Williams method, 2) to analyze the distribution of runoff coefficient in Babura river basin. In this research, data were collected using survey methods both the institutional and field surveys. Institutional surveys were used to obtain rainfall and land use data meanwhile field surveys were used to gain soil texture data and slope. The results of this study were analyzed using descriptive and spatial analysis. The results showed that the runoff coefficient in the Babura watershed was from 0.4 to 0.55 with an average of 0.475 . This means that the Babura watershed is still in good condition. Furthermore, runoff coefficient in upstream was $0.4-0.45$ while in downstream the runoff coefficient was $0.5-0.55$.

Key words: runoff coefficient, Bransby-Williams, Watershed, Babura

\section{PENDAHULUAN}

Daerah Aliran Sungai merupakan sebuah ekosistem yang didalamnya terjadi interaksi antara komponen abiotik, biotic dan social. Satu komponen akan mempengaruhi komponen yang lain sehingga apabila terjadi kerusakan pada salah satu komponen pada ekosistem tersebut maka akan menyebabkan terganggunya komponen lainnya. Salah satu penyebab terjadinya kerusakan pada daerah aliran sungai adalah alih fungsi 
lahan. Perubahan penggunaan lahan dapat mempengaruhi system hidrologi dan berdampak besar pada sumber daya air (Wagner, P.D, Kumar, S, Schnieder, K, 2013). Alih fungsi lahan yang memberikan konsekuensi pada perubahan penutup lahan akan menyebabkan semakin tingginya limpasan permukaan. Limpasan permukaan yang tinggi merupakan salah satu parameter yang mengindikasikan telah terjadinya kerusakan DAS.

Sub Daerah Aliran Sungai Babura merupakan bagian dari Daerah Aliran Sungai Deli. Secara administrasi, Sub Daerah Aliran Sungai Babura mencakup wilayah Kabupaten Deli Serdang dan Kota Medan dengan luas wilayah 4921,88 Ha. Sungai utama yang mengalir di Sub DAS Babura adalah sungai Babura yang merupakan cabang dari sungai Deli.

Kondisi hidrologi sebagian Kota Medan sangat dipengaruhi oleh sub Daerah Aliran Sungai Babura dimana sebagian wilayah Kota Medan termasuk dalam system DAS tersebut. Sebagian dari kota Medan termasuk bagian hilir dari subDAS Babura yang umumnya digunakan sebagai daerah pemanfaatan (discharge area) sehingga potensi sumber daya airnya sangat tergantung pada daerah hulu (Kecamatan Sibolangit, Kabupaten Deli Serdang). Daerah hulu tersebutlah yang berfungsi utama sebagai daerah tangkapan air (recharge area) sehingga kondisi fisik daerah hulu sangat berpengaruh terhadap limpahan air yang akan diterima di daerah hilir, yaitu Kota Medan.

Alih fungsi lahan di daerah tangkapan air (Sibolangit) maupun daerah pemanfaatan (Kota Medan) memicu terjadinya peningkatan limpasan permukaan. Hal ini menyebabkan ketersediaan air pada musim kemarau menjadi defisit sedangkan pada musim penghujan, ketersediaan air melimpah. Namun, ketersediaan air pada musim penghujan tersebut adalah ketersediaan air yang tidak bisa dimanfaatkan oleh manusia karena langsung didistribusikan ke laut. Peningkatan limpasan permukaan di musim penghujan akan memicu terjadinya banjir di hilir Sungai Babura. Seperti kejadian banjir yang terjadi pada hilir sungai Babura dari tahun ke tahun. Bulan April 2011 ketinggian banjir mencapai 2 meter dan merendam ratusan rumah. Tahun 2014, ketinggian banjir juga mencapai 2 meter terjadi di sebagian daerah Medan Selayang. Analisis koefisien aliran menjadi sangat diperlukan untuk mengetahui sebaran limpasan permukaan yang dapat memicu terjadinya banjir di bagian hilir sungai.

\section{METODE PENELITIAN}

Penelitian ini dilakukan di sub Daerah Aliran Sungai Babura yang mencakup dua wilayah administrasi, yaitu Kabupaten Deli Serdang dan Kota Medan. Bahan yang digunakan dalam penelitian ini terdiri dari Peta Rupa Bumi Indonesia skala 1 : 50.000, Peta Kemiringan Lereng, Peta Tanah dan Peta Penggunaan Lahan sedangkan alat yang digunakan adalah GPS dan abney level. Pengumpulan data dilakukan dengan mengunakan metode survey baik survey instansional maupun survey lapangan. Data yang digunakan dalam penelitian ini meliputi curah hujan, kemiringan lereng, tekstur tanah, vegetasi penutup dan simpanan permukaan. Selanjutnya data tersebut diolah dengan menggunakan metode Bransby-Williams untuk mendapatkan besarnya nilai koefisien aliran. Nilai koefisien aliran yang didapatkan merupakan hasil penjumlahan harkat dari lima parameter (curah hujan, lereng, kemampuan infiltrasi, vegetasi penutup dan simpanan permukaan).

Tabel 1. Menunjukkan estimasi koefisien aliran permukaan dengan menggunakan metode Bransby-Williams. Analisis hasil yang digunakan dalam penelitian ini adalah analisis deskriptif dan analisis spasial. Secara singkat, tahapan penelitian yang dilaksanakan pada penelitian ini dapat dilihat pada Gambar 1. 
Tabel 1. Estimasi Koefisien Aliran Permukaan dengan Metode Bransby-Williams

\begin{tabular}{|c|c|c|c|c|}
\hline \multirow{2}{*}{$\begin{array}{l}\text { Karakteristik } \\
\text { DAS yang } \\
\text { dipertimbangka } \\
\mathrm{n}\end{array}$} & \multicolumn{4}{|c|}{ Karakteristik yang menghasilkan aliran } \\
\hline & 100 (ekstrim) & 75 (tinggi) & 50 (normal) & 25 (rendah) \\
\hline Relief & $\begin{array}{l}\text { Medan terjal } \\
\text { kasar dengan } \\
\text { lereng rata-rata } \\
\text { umumnya diatas } \\
20 \% \\
\quad(10)\end{array}$ & $\begin{array}{l}\text { Perbukitan } \\
\text { dengan lereng } \\
\text { rata-rata antara } \\
10-20 \% \\
(5)\end{array}$ & $\begin{array}{l}\text { Bergelombang } \\
\text { dengan lereng } \\
\text { rata-rata antara 5- } \\
10 \% \\
(0)\end{array}$ & $\begin{array}{l}\text { Lahan } \\
\text { relatif datar } \\
\text { dengan } \\
\text { lereng } 0-5 \% \\
(0)\end{array}$ \\
\hline Infiltrasi tanah & $\begin{array}{l}\text { Tidak ada } \\
\text { penutup tanah } \\
\text { efektif, } \\
\text { Batuan padatan } \\
\text { maupun batuan } \\
\text { tipis }\end{array}$ & $\begin{array}{l}\text { Infiltrasi air } \\
\text { lambat, tanah } \\
\text { solodic, jika } \\
\text { rusak } \\
\text { permukaannya } \\
\qquad(20)\end{array}$ & $\begin{array}{l}\text { Tanah geluh, } \\
\text { berstruktur } \\
\text { lempung } \\
\text { lempung = } \\
\text { chernozem } \\
\qquad(10)\end{array}$ & $\begin{array}{l}\text { Pasir dalam } \\
\text { atau tanah } \\
\text { teragregasi } \\
\text { baik= } \\
\text { krasbozem } \\
\qquad(5)\end{array}$ \\
\hline Penutup lahan & $\begin{array}{l}\text { Tidak ada } \\
\text { tanaman penutup } \\
\text { (tanaman keras) } \\
\text { yang efektif }\end{array}$ & $\begin{array}{l}\text { Sheet erosion } \\
\text { kurang dari } \\
10 \% \text { dibawah } \\
\text { padang } \\
\text { rumput, sedikit } \\
\text { tanaman } \\
\text { pertanian } \\
(20)\end{array}$ & $\begin{array}{l}50 \% \text { tertutup } \\
\text { baik, tanaman } \\
\text { pertanian } \\
\text { berkayu tidak } \\
\text { lebih } 50 \% \\
\text { (10) }\end{array}$ & $\begin{array}{l}90 \% \text { DAS } \\
\text { tertutup } \\
\text { baik oleh } \\
\text { rumput, } \\
\text { hutan } \\
\text { kering } \\
\qquad(5)\end{array}$ \\
\hline $\begin{array}{c}\text { Simpanan } \\
\text { permukaan }\end{array}$ & $\begin{array}{l}\text { Beberapa depresi } \\
\text { permukaan, alur } \\
\text { sungai terjal, } \\
\text { overland flow } \\
\text { tipis dapat } \\
\text { diabaikan } \\
\qquad(10)\end{array}$ & $\begin{array}{l}\text { Sistem drainase } \\
\text { baik }\end{array}$ & $\begin{array}{l}\text { Depresi } \\
\text { permukaan } \\
\text { overlandflow } \\
\text { berarti, terdapat } \\
\text { beberapa telaga } \\
\text { dan rawa, alur- } \\
\text { alur sungai } \\
\qquad(5)\end{array}$ & \begin{tabular}{l} 
Drainase \\
jelek, \\
meander, \\
Dd besar \\
dan $90 \%$ \\
konservasi \\
tanah \\
\multicolumn{1}{c}{$(0)$}
\end{tabular} \\
\hline Intensitas Hujan & $\begin{array}{c}3-4 \text { inci/jam } \\
\text { (30) }\end{array}$ & $\begin{array}{c}2-3 \text { inci/jam } \\
(25)\end{array}$ & $\begin{array}{c}1-2 \text { inci/jam } \\
\text { (15) }\end{array}$ & $\begin{array}{c}1 \text { inci/jam } \\
(15)\end{array}$ \\
\hline
\end{tabular}

Sumber : Meyerink, 1970

\section{HASIL DAN PEMBAHASAN}

\section{A. Koefisien Aliran}

Koefisien aliran ditentukan dengan menggunakan beberapa parameter fisik dari wilayah daerah aliran sungai. Parameter yang digunakan oleh Bransby-William untuk penentuan koefisien aliran terdiri dari kemiringan lereng, morfometri DAS (simpanan permukaan), infiltrasi, vegetasi penutup dan intensitas hujan.

\section{Kemiringan Lereng}

Kemiringan lereng berpengaruh terhadap aliran yang terjadi di suatu wilayah. semakin besar kemiringan lereng maka akan menyebabkan aliran semakin besar. Hal ini disebabkan oleh kemiringan lereng yang besar akan memberikan kesempatan air hujan meresap ke dalam tanah dengan jumlah yang relative kecil. Kemiringan lereng di Sub DAS Babura cukup bervariasi jika 
dilihat dari hulu sampai hilir sungai.

Kemiringan lereng di Sub DAS Babura

dapat dilihat seperti pada Tabel 2.

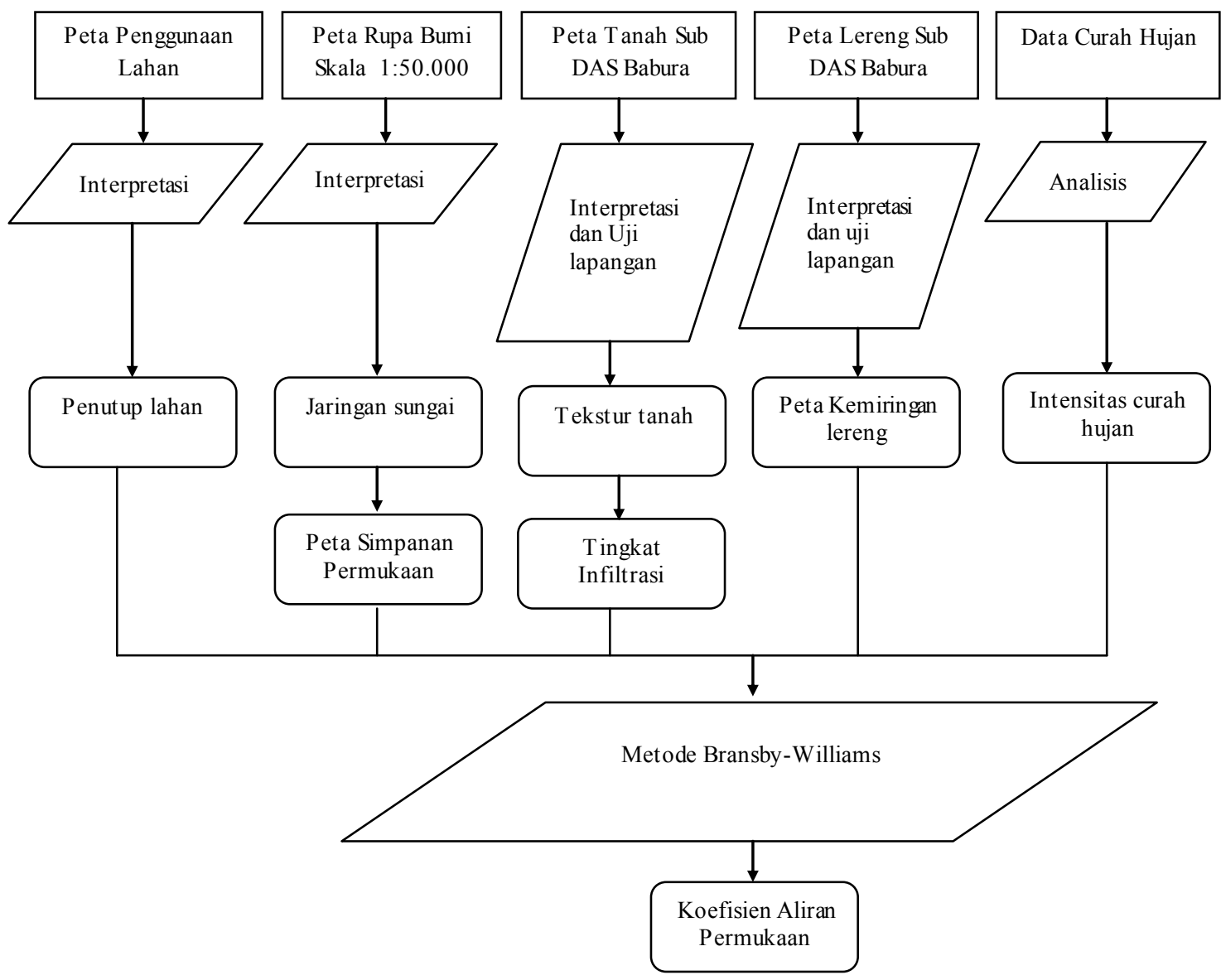

Gambar 1. Tahapan Penelitian

Tabel 2. Kemiringan Lereng di Sub DAS Babura

\begin{tabular}{|c|l|l|r|r|}
\hline No & $\begin{array}{c}\text { Kemiringan } \\
\text { Lereng }\end{array}$ & Morfologi & $\begin{array}{c}\text { Luas } \\
(\mathrm{Ha})\end{array}$ & $\begin{array}{c}\text { Persen } \\
\text { Luas } \\
(\%)\end{array}$ \\
\hline 1 & $0-2 \%$ & Dataran & $3.455,82$ & 70,21 \\
\hline 2 & $3-7 \%$ & Berombak & 977,06 & 19,85 \\
\hline 3 & $8-13 \%$ & Bergelombang & 489,00 & 9,94 \\
\hline \multicolumn{3}{|c|}{ Luas Total } & 4921,88 & 100,00 \\
\hline
\end{tabular}

Sumber : Analisis Peta Lereng, 2015

\section{Simpanan Permukaan}

\section{Simpanan}

permukaan diperhitungkan dengan menentukan kerapatan alur. Semakin besar kerapatan alur maka simpanan permukaan akan semakin kecil. Kerapatan alur sungai menyatakan panjang alur sungai pada setiap satuan luas DAS atau sub DAS, yaitu mil panjang sungai per mil² luas areal. Panjang Sungai Babura adalah 45,31 mil dengan luas 19 mil $^{2}$. Berdasarkan panjang dan luas tersebut maka diperoleh kerapatan alur di sub Daerah Aliran Sungai Babura adalah 2,38 $\mathrm{mil} / \mathrm{mil}^{2}$ (system saluran baik). 


\section{Infiltrasi}

Infiltrasi diperkirakan dengan analisis tekstur tanah pada beberapa jenis tanah yang ada di Sub DAS Babura. Semakin kasar tekstur tanah yang ada di suatu daerah maka infiltrasi akan semakin cepat dan semakin halus tekstur tanah maka infiltrasi akan semakin lambat. Tekstur tanah diSub DAS Babura dapat dilihat pada Tabel 3.

Tabel 3. Jenis Tanah dan Tekstur Tanah di Sub DAS Babura

\begin{tabular}{|c|c|c|}
\hline Jenis Tanah & Tekstur Tanah & Infiltrasi \\
\hline $\begin{array}{c}\text { Tropaquepts } \\
\text { Dystropepts }\end{array}$ & $\begin{array}{c}\text { Geluh } \\
\text { berlempung } \\
\text { Geluh berdebu }\end{array}$ & Normal \\
\hline Eutrandepts & Geluh berpasir & Normal \\
\hline $\begin{array}{c}\text { Dystropepts } \\
\text { Kandiudults } \\
\text { Tropaquepts }\end{array}$ & $\begin{array}{c}\text { Lempung } \\
\text { berpasir }\end{array}$ & Normal \\
\hline & $\begin{array}{c}\text { Lempung } \\
\text { berdebu } \\
\text { Lempung } \\
\text { berpasir }\end{array}$ & Normal \\
\hline
\end{tabular}

Sumber : Analisis Peta Tanah dan Survei Lapangan, 2015

\section{Vegetasi Penutup}

Vegetasi penutup dapat ditentukan dengan melihat jenis penggunaan lahan yang terdapat pada satu daerah. Bentuk penggunaan lahan di Sub DAS Babura bervariasi dari hulu ke hilir. Di daerah hulu sungai Babura, lahan umumnya digunakan untuk pertanian lahan kering yang bercampur dengan semak dan tegalan. Tegalan dan pertanian lahan kering dimanfaatkan untuk menanam kelapa sawit. Selain itu, pertanian lahan kering yang diusahakan oleh penduduk juga ditanami dengan tanaman semusim seperti tanaman jagung. Sedangkan di daerah hilir sungai Babura lebih banyak dimanfaatkan untuk permukiman dan instalasi prasarana. Perkembangan dan perluasan kota Medan yang cukup pesat mempengaruhi perkembangan permukiman di Sub DAS Babura. Hal ini sangat mempengaruhi alih fungsi lahan yang terjadi di Sub DAS tersebut. Alih fungsi lahan menjadi permukiman cenderung akan menyebabkan peningkatan koefisien aliran. Luas penggunaan lahan yang ada di Sub DAS Babura seperti terlihat pada Tabel 4 .

Tabel 4. Luas Penggunaan Lahan di Sub DAS Babura

\begin{tabular}{|c|c|c|c|}
\hline No & Penggunaan Lahan & $\begin{array}{c}\text { Luas } \\
(\mathrm{Ha})\end{array}$ & $\begin{array}{c}\text { Persen } \\
\text { Luas }(\%)\end{array}$ \\
\hline 1 & Permukiman & 1316,82 & 26,75 \\
\hline 2 & Kebun campuran & 1211,66 & 24,62 \\
\hline 3 & $\begin{array}{c}\text { Pertanian Lahan Kering } \\
\text { Bercampur Semak }\end{array}$ & 2030,74 & 41,26 \\
\hline 4 & $\begin{array}{c}\text { Tanah Terbuka/Instalasi } \\
\text { Prasarana }\end{array}$ & 186,46 & 3,79 \\
\hline 5 & Tegalan & 176,20 & 3,58 \\
\hline
\end{tabular}




\begin{tabular}{|c|c|c|}
\hline Luas Total & 4921,88 & 100,00 \\
\hline
\end{tabular}

Sumber : Analisis Peta Penggunaan Lahan, 2015

\section{Intensitas Hujan}

Intensitas curah hujan merupakan salah satu faktor yang mempengaruhi besarnya aliran di suatu wilayah. Intensitas curah hujan menyatakan tebal hujan dibandingkan dengan lamanya hujan yang terjadi disuatu tempat. Intensitas curah hujan pada beberapa stasiun hujan di Sub DAS Babura dapat dilihat pada Tabel 5 .

Tabel 5. Intensitas Hujan di Tiga Stasiun di Sub DAS Babura

\begin{tabular}{|c|c|}
\hline Nama Stasiun & $\begin{array}{c}\text { Intensitas Hujan } \\
(\mathrm{mm} / \text { jam })\end{array}$ \\
\hline Pancur Batu & 1,19 \\
\hline Sampali & 1,01 \\
\hline Helvetia & 1,12 \\
\hline \multicolumn{2}{|c|}{ Sumber : Analisis Data Curah Hujan, 2015 }
\end{tabular}

Berdasarkan ke lima parameter diatas yang terdiri dari kemiringan lereng, infiltrasi, simpanan permukaan, penutup lahan dan intensitas curah hujan maka dapat diperhitungkan nilai koefisien aliran di Sub DAS Babura. Rata-rata koefisien aliran Sub DAS Babura adalah 47,5\%. Hal ini dapat dikatakan bahwa 47,5 persen curah hujan yang jatuh di Sub DAS Babura akan menjadi aliran permukaan dan sekitar 52,5 persen yang akan terinfiltrasi ke dalam tanah.

\section{B. Distribusi Koefisien Aliran}

Nilai koefisien aliran di sub Daerah Aliran Sungai Babura bervariasi. Koefisien aliran $40-45 \%$ terdapat pada hulu Sub DAS Babura sedangkan koefisien aliran 50 - 55\% terdapat pada hilir Sub DAS Babura. Perbedaan besarnya koefisien aliran permukaan di Sub DAS Babura disebabkan oleh adanya parameter lingkungan fisik yang berbeda pada sub DAS tersebut. Koefisien aliran terbesar $(0,55$ atau 55 persen $)$ terjadi pada daerah dengan penggunaan lahan bandara (instalasi prasarana) di Kecamatan Medan Polonia.

Hal ini mengingat semua bagian dari lahan tertutup oleh bangunan sehingga separuh dari air hujan yang jatuh akan menjadi aliran permukaan. Koefisien aliran paling rendah $(0,4$ atau 40 persen) terdapat pada penggunaan lahan pertanian lahan kering bercampur semak pada kemiringan lereng 0 - $13 \%$. Sebaran koefisien aliran permukaan di Sub DAS Babura dapat dilihat pada Gambar 2.

\section{KESIMPULAN}

1.Nilai koefisien aliran di Sub DAS Babura adalah 47,5\%. Hal ini berarti bahwa air hujan yang jatuh di Sub DAS Babura 47,5 persennya akan menjadi aliran permukaan sedangkan 52,5 persen akan terinfiltrasi ke dalam tanah.

2.Koefisien aliran di hilir daerah aliran sungai lebih besar dibandingkan dengan koefisien aliran di daerah hulu. Hal ini dipengaruhi oleh kondisi penggunaan lahan yang ada di Sub DAS Babura dimana pada bagian hilir DAS, penggunaan lahan yang banyak ditemui adalah permukiman dan instalasi prasarana. Permukiman dan instalasi prasarana cenderung mempunyai vegetasi yang terbatas sehingga menyebabkan aliran permukaan menjadi lebih tinggi. 


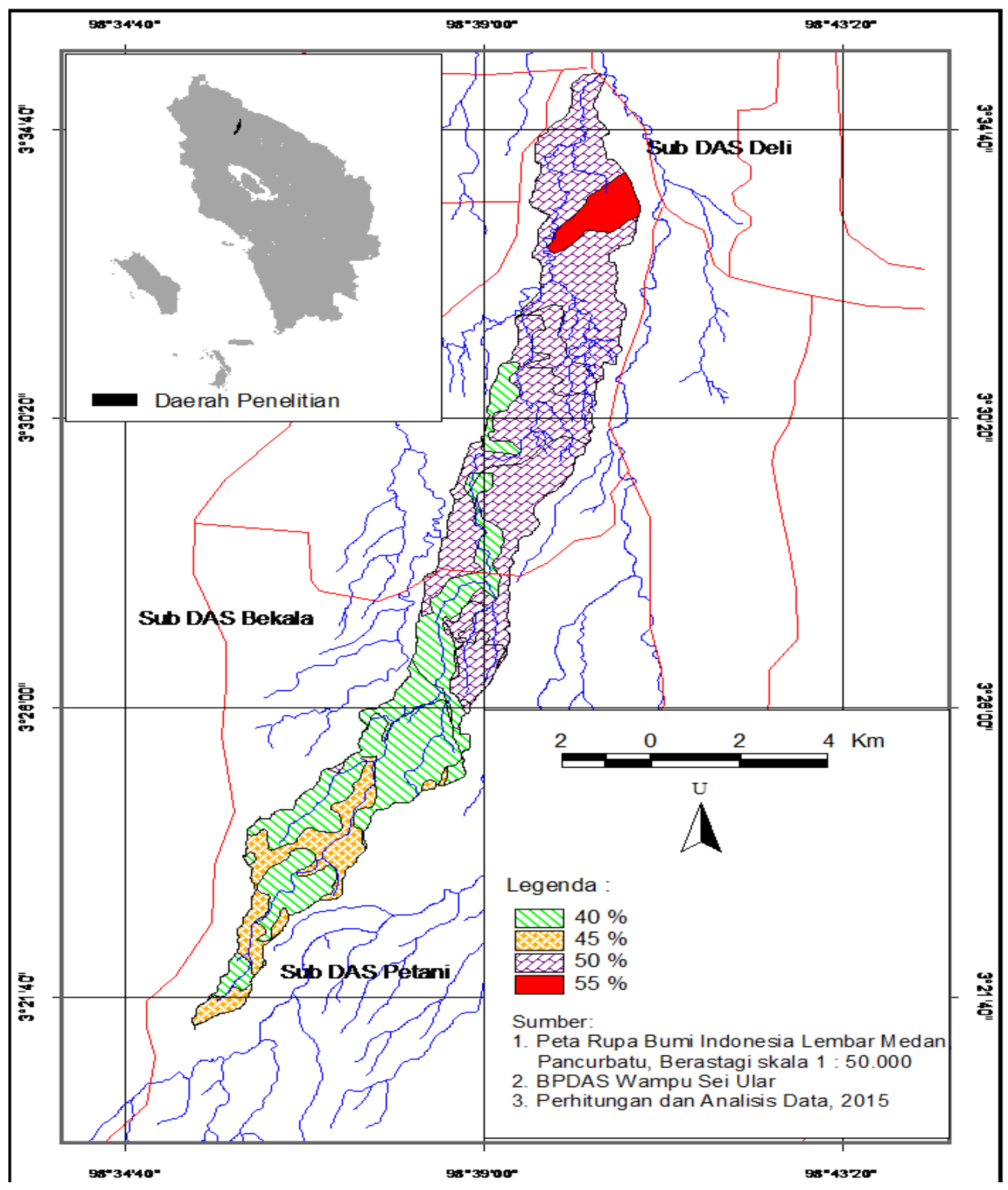

Gambar 2. Peta Sebaran Koefisien Aliran di Sub Daerah Aliran Sungai Babura

\section{DAFTAR PUSTAKA}

Arsyad, S, 1989, Konservasi Tanah dan Air,

Penerbit IPB, Bogor

Asdak, C, 1995, Hidrologi dan Pengelolaan

Daerah Aliran Sungai, Gadjah Mada

University Press, Yogyakarta
Astuti dan Berutu, 2011, Studi Mengenai Koefisien Aliran sebagai Indikator Kerusakan Lingkungan di Daerah Aliran Sungai Deli, Laporan Penelitian, Universitas Negeri Medan 
Astuti, dkk, 2012, Analisis Tingkat Kerentanan Banjir Dengan Pendekatan Geoekosistem di SubDAS Babura Provinsi Sumatera Utara

Gunawan, T, 1991, Penerapan Teknik Penginderaan Jauh Untuk Menduga Debit Puncak Menggunakan Karakteristik Lingkungan Fisik DAS, Disertasi, Fakultas Pasca Sarjana, Institut Pertanian Bogor

Marwah, 2001, Daerah Aliran Sungai Sebagai Satuan Unit Perencanaan Pembangunan Pertanian Lahan Kering Berkelanjutan, Program Pasca Sarjana, IPB

Meyerink, A.M.J, 1970, Photo-Interpretation in Hidrology, A Geomorphological Approach, International Institute for Aerial Survey and Earth Sciences (ITC), 3 Kanaalweg, Delf, The
Netherlands

Raharjo, 2009, Perubahan Penggunaan Lahan DAS Kreo Terhadap Debit Puncak dengan Aplikasi Penginderaan Jauh, Jurnal

Seyhan, E, 1990, Dasar-Dasar Hidrologi, Gadjah Mada University Press, Yogyakarta

Sosrodarsono, Suyono, 1977, Hidrologi Untuk Pengairan, Penerbit Pradyna Paramita, Jakarta

Wagner, P.D, Kumar, S, Schnieder, K. (2013). An Assesment of Land Use Change Impact On the Water Resources of the Mula and Mutha Rivers Catchment Upstream of Pune India. hydrology and Earth System Sciences , 14 